\title{
Pelatihan homestay dan inovasi kuliner sebagai strategi pemberdayaan perempuan dalam pariwisata
}

\author{
Rini Kartika Hudiono ${ }^{*}$, Evi Maria $₫$, \& Suharyadi \\ Universitas Kristen Satya Wacana \\ *rini.hudiono@uksw.edu
}

\begin{abstract}
Abstrak. Pengabdian masyarakat dilakukan di Dusun Srumbung Gunung bertujuan melibatkan perempuan. Dusun ini mengembangkan Desa Wisata Kreatif Perdamaian dan produk yang dikembangkan adalah paket live-in. Untuk melibatkan perempuan dilakukan pelatihan homestay dan inovasi kuliner, di mana sebagian perempuan yang terlibat kehilangan pekerjaan karena Pandemi Covid 19. Metode yang dilakukan adalah pendekatan eksploratif kualitatif dengan beberapa tahap. Pertama adalah identifikasi ketersediaan rumah yang akan dijadikan homestay melalui wawancara dan observasi. Selanjutnya mengidentifikasi bahan baku yang tersedia dan diproduksi secara lokal. Tahap tiga adalah melakukan riset jenis makanan kecil yang bisa dibuat dengan bahan yang tersedia, memiliki rasa yang enak serta harga jual yang baik di pasar, dan mudah pembuatannya dengan alat yang sederhana. Tahap empat adalah memilih peserta perempuan yang tertarik untuk terjun dalam wirausaha produk kuliner serta memiliki ketrampilan dasar membuat kue. Tahap ke lima, pelatihan homestay dengan konsep Clean, Healthy, Safe and Environmentally Sustainable, pelatihan inovasi kuliner membuat bolen pisang dan taped an pendampingan praktek homestay dan perintisan usaha pembuatan bolen pisang dan tape. 2 dari 22 peserta pelatihan sudah melakukan persiapan produksi bolen untuk dijual. Hasil menunjukkan, keterlibatan perempuan dalam pariwisata terbatas dalam pendanaan, pengalaman dan ketrampilan berwirausaha serta tanggung jawab yang harus dilakukan sebagai Ibu rumah tangga.
\end{abstract}

Kata kunci: pemberdayaan perempuan, homestay, inovasi kuliner, Srumbung Gunung

\begin{abstract}
The community service activities conducted in Srumbung Gunung was to involve women. Dusun Srumbung Gunung is developing a creative peace tourism village and the tourist products developed is a package program of live. In order to involve women in tourism, the training of homestay and culinary innovation was held, in which some women lost their job due to Covid 19 Pandemic. The method used was explorative qualitative with some stages. The first stage was to identify the house availability for homestay through interview and observation. Next was to identify the ingredient available and produced locally. The third stage was to research the type of snack which can be made with the available ingredient, good flavour and good price, easy to make with simple tools. Besides, the product can be produced as typical and unique food for tourists. Following this step was to choose women involved especially those who are interested in the food business and owning basic baking skill. The fifth step was the training of homestay with the concept of Clean, Healthy, Safe and Environmentally Sustainable, the training of culinary innovation was making bolen pisang and tape. The last stage was the mentoring process of homestay and the start-up food business of bolen pisang and tape. Two of the twenty-two women joined has started to prepare the business. The results showed that women involvement in tourism limited to fund, entrepreneurship experience and skill and the responsibility as housewives.
\end{abstract}

Keywords: women empowerment, homestay, culinary innovation, Srumbung Gunung

To cite this article: Hudiono, R. K., E. Maria., \& Suharyadi . 2020. Pelatihan homestay dan inovasi kuliner sebagai strategi pemberdayaan perempuan dalam pariwisata. Unri Conference Series: Community Engagement 2: 169-176. https://doi.org/10.31258/unricsce.2.169-176

(C) 2020 Authors

Peer-review under responsibility of the organizing committee of Seminar Nasional Pemberdayaan Masyarakat 2020 


\section{PENDAHULUAN}

Peran perempuan dalam masyarakat sering diabaikan dan bahkan diperdebatkan. Istilah pemberdayaan perempuan menjadi seolah-olah tidak memiliki kekuasaannya dalam masyarakat. Dalam diskusi Forum International Perserikatan Bangsa-Bangsa (PBB) mengenai Millienium Development Goal (MDG), terdapat lima dari delapan poin membahas langsung mengenai pemberdayaan perempuan. Poin tersebut adalah mempromosikan persamaan gender dan pemberdayaan perempuan. Menariknya adalah dalam pembahasan ini adalah pemberdayaan perempuan berkaitan dengan pemberantasan kemiskinan dan kelaparan, pencapaian pendidikan dasar, pengurangan tingkat kematian anak dan peningkatan kesehatan perempuan. Hal ini menunjukkan betapa peran wanita sangatlah penting. Praktiknya wanita yang diperdayakan akan dapat berkontribusi kepada pertumbuhan ekonomi masyarakat yang berarti berkontribusi mengurangi kemiskinan dan kelaparan, memungkinkan mereka untuk mendukung anak-anak dalam Pendidikan dan dengan memperoleh pengetahuan, Pendidikan dan kesehatan yang lebih baik berarti juga bisa mengurangi angka kematian anak.

Dalam pariwisata, pemberdayaan perempuan pun dipercayai dapat secara positif mengurangi kemiskinan, isu kesetaraan gender dan masalah lainnya. Bahkan menurut UNWTO (2008), 60\% hingga 70\% tenaga kerja di pariwisata didominasi oleh perempuan. Menurut Hemmati (1999), 46\% tenaga kerja pariwisata dunia adalah perempuan dan terus meningkat setiap tahunnya. Organisasi Pariwisata Dunia yang dikenal dengan UNWTO meluncurkan Women in Tourism Empowerment Programs (WITEP) bulan Oktober 2011. Pemberdayaan perempuan dapat dinilai dari Indeks Pemberdayaan Gender (IDG), tapi belum terdapat data mengenai jumlah pasti perempuan yang bekerja di sektor pariwisata. Namun, pembangunan pariwiata berbasis masyarakat tentunya harus juga melibatkan perempuan.

Dusun Srumbung Gunung secara administrasi terletak di Desa Poncoruso yang sedang mengembangkan Desa Wisata Kreatif Perdamaian. Dengan luas $1.27 \mathrm{~km} 2$, Desa Poncoruso memiliki 2.341 jumlah penduduk dengan kepadatan penduduk 1.843.31/km2. Desa Poncoruso memiliki jumlah penduduk pria 1.187 dan perempuan yang hampir sama jumlahnya, yaitu 1.154. 24,83\% pendudukanya belum/tidak pekerja dan 65 orang bekerja sebagai ibu rumah tangga. Penduduk yang bekerja sebagai karyawan swasta sebesar 26,40\%, buruh harian lepas sebesar 6,96\%, petani/pekebun sebesar 7,43\% dan sisanya adalah buruh tani/perkebunan, pegawai negeri sipil, tentara dan perdagangan yang masing-masing kurang dari 1\%. Dengan kondisi Covid 19, tentunya tidak sedikit penduduk yang kehilangan pekerjaan, tak terkecual kaum perempuan di Dusun Srumbung Gunung, Desa Poncoruso. Menurut data BPS Kabupaten Semarang, Desa Poncoruso belum memiliki pasar dan mini market dan terdapat 16 toko/warung kelontong dengan 4 warung/kedai makan. Desa ini juga tidak memiliki rumah makan, hotel ataupun penginapan.

Empat komponen utama pariwisata dalah amenitas, akomodasi, atraksi dan aksesibilitas. Apabila Dusun Srumbung Gunung ingin mengembangkan Desa Wisata Kreatif Perdamaian, maka ke empat komponen tersebut harus dipenuhi. Untuk aksesibilitas, letak Dusun Srumbung Gunung sangatlah strategis, tidak jauh dari Semarang, Ambarawa dan Salatiga. Nilai-nilai kerukunan dan toleransi penduduknya ditambah bentangan alam, di mana Dusun ini terletak di lereng Gunung Ungaran dengan ketinggian 500 mdpl menjadi keunggulan atraksi atau daya tarik wisata. Dengan tidak adanya hotel atau penginapan dan minimnya tempat makan, serta isu pemberdayaan perempuan dalam pariwisata di Srumbung Gunung inilah, kegiatan Pengabdian kepada Masyarakat dalam Program Pendampingan Desa Mitra UKSW yang dibiayai RISTEKDIKTI mencoba menjalankan program pelatihan dan pendampingan perempuan melalui program homestay dan pelatihan inovasi kuliner.

Menurut (Studi et al., n.d.), pariwisata menawarkan peluang kerja bagi perempuan dan sifat pekerjaan ini erat kaitannya dengan karakteristik pekerjaan yang digeluti perempuan di rumah tangga mereka seperti memasak atau membersihkan rumah. Sehingga melibatkan perempuan dalam bisnis makanan adalah tepat karena mereka bisa memulai usaha yang mendukung pariwisata dan sekaligus dapat tetap menjalani peran sebagai ibu rumah tangga dan melakukan tanggung jawab sebagai istri dan ibu. Rendahnya tingkat pendidikan dan minimnya pengalaman dalam bidang pariwisata di kalangan perempuan di Dusun Srumbung Gunung membuat program pendampingan dan pelatihan menjadi sangat penting.

Beeton (2019) menyebutkan bahwa proses pemberdayaan manusia atau komunitas adalah aspek yang penting pemberdayaan karena proses itu sama pentingnya adalah luaran/capaian dari pemberdayaan. Kata kunci dari pernyataan ini adalah pentingnya proses dan pemberdayaan itu adalah sebuah proses. Oxaal \& Baden (1997) menambahkan bahwa pemberdayaan perempuan haruslah proses bottom-up, di mana wanita harus dapat memperdayakan dirinya sendiri untuk mendapatkan hasilnya sendiri. Dengan kata lain, keinginan 
dan motivasi untuk memperdayakan dirinya sendiri menjadi faktor yang penting. Pemberdayaan perempuan yang disebutkan oleh Wiser Earth (2005) mengacu kepada kemampuan perempuan dalam mentransformasi pertumbuhan ekonomi dan sosial saat diberdayakan sehingga dapat berpartisipasi secara penuh melalui pelatihan kepemimpian, coaching, consulting dan pemenuhan alat-alat yang dibutuhkan mereka. Harapannya adalah melalui proses inilah, perempuan mendapat penghasilan yang dpat memenuhi kebutuhan hidup yang meningkat, pelayanan kesehatan dan Pendidikan untuk anak-anak mereka (Van der Cammen, 1997). UNWTO juga memperkuat bahwa positif kontribusi pariwisata dalam pemberdayaan perempuan dapat ditentukan jika kemiskinan berkurang dan harga diri wanita meningkat dan pekerjaan dapat diperoleh. Konseptual model pemberdayaan perempuan melalui pariwisata dari perspective socio entrepeneurship (Irena, 2009) menjelaskan bahwa elemen penting dalam pemberdayaan perempuan adalah socio entrepreneurship dan disini kuncinya adalah pariwisata. Apabila perempuan sudah dapat diberdayakan, makan pintu akan terbuka. Hal ini berarti bahwa perempuan yang diberdayakan dapat menghapuskan kemiskinan dan kelaparan, mempromosikan kesetaraan gender, meningkatkan kesehatan perempuan dan mengurangi kematian perempuan serta mencapai pendidikan dasar anak mengurangi angka kematian anak.

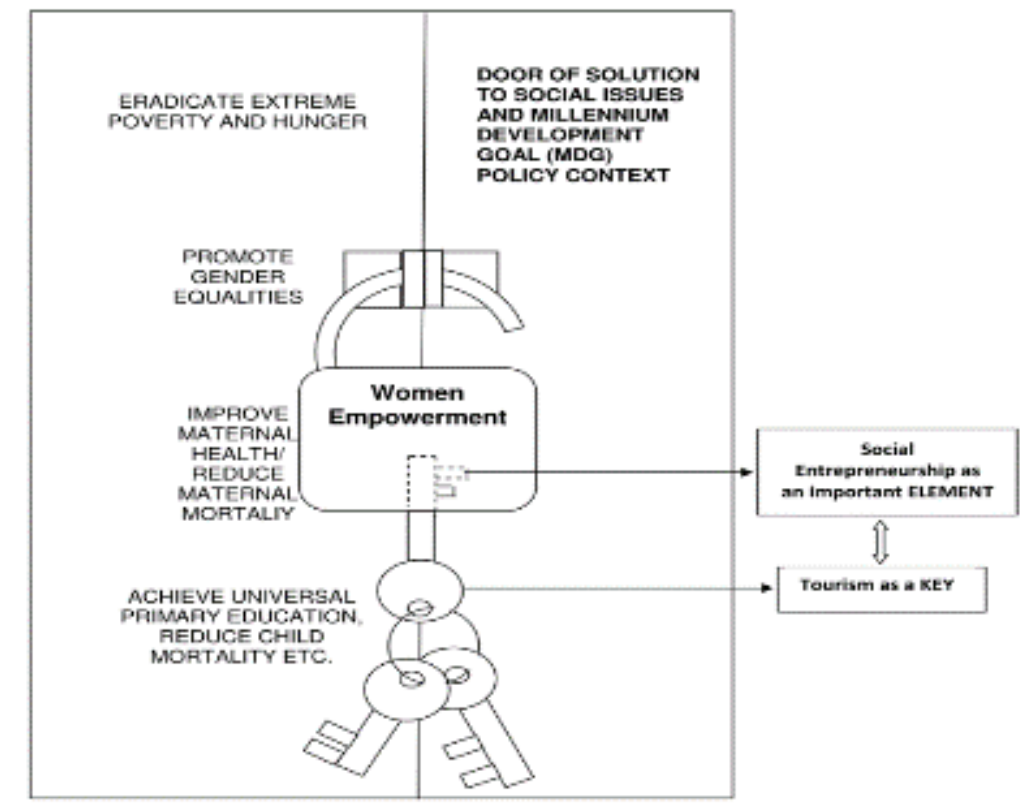

Gambar 1. Conceptual Map of Door, Lock and Key Concept for Women Empowerment through Tourism from Socio Entrepreneurship Perspective

Kata kunci dari konseptual model di atas adalah socio-entrepeneurship, yang disebut Ashoka dalam Sen (2007), bahwa istilah ini menggambarkan individu-individu yang mengkombinasikan praktek dan metode berorientasikan hasil dari bisnis kewirausahaan dengan tujuan sosial. Fowler (2000) menambahkan bahwa misi socio-entrepreneurship adalah menciptakan surplus daripada keuntungan.

Dari penjelasan di atas, program pemberdayaan perempuan di Dusun Srumbung Gunung yang dijalankan dalam Program Pendampingan Desa Mitra adalah tepat. Para Ibu-Ibu PKK yang sebagian kehilangan pekerjaan karena Pandemi Covid 19, dapat merintis usaha kuliner dan homestay yang adalah secara karakteristik adalah pekerjaan mereka sehari-hari. Selain itu, apabila bisnis ini berjalan di bawah Organisasi Pengelola DWKP (Desa Wisata Kreatif Perdamaian), maka hal ini dapat menjadi bisnis yang prakteknya dikombinasikan dengan tujuan sosial. Harapannya adalah mensejahterahkan Dusun melalui pariwisata yang dikembangkan berarti juga mensejahterakan perempuan-perempuannya. Mensejahterakan perempuan-perempuannya berarti juga mensejahterakan anak-anak mereka.

\section{METODE PENERAPAN}

Lokasi kegiatan Pengabdian kepada Masyarakat adalah Desa Wisata Kreatif Perdamaian, Dusun Srumbung Gunung. Tepatnya adalah Desa Poncoruso, Kecamatan Bawen, Kabupaten Semarang. Kegiatan ini dilakukan sebagai kegiatan Program Pendampingan Desa Mitra yang didanai oleh Ristek DIKTI pada tahun 2020.Program pemberdayaan perempuan dilakukan menggunakan pendekatan eksploratif kualitatif. 
Program ini dilaksanakan dengan serangkaian tahap. Tahap pertama adalah mengidentifikasi ketersediaan rumah yang akan dijadikan homestay melalui wawancara dan observasi. Tahap kedua adalah mengidentifikasi bahan baku yang tersedia dan banyak diproduksi secara lokal. Tahap ke tiga adalah melakukan riset jenis makanan kecil yang bisa dibuat dengan bahan yang tersedia, memiliki rasa yang enak serta harga jual yang baik di pasar, dan mudah pembuatannya dengan alat-alat yang sederhana. Selain itu, jenis makanan ini bisa dijadikan oleh-oleh khas sebagai salah satu produk yang bisa dikembangkan. Tahap ke empat adalah memilih peserta perempuan yang tertarik untuk terjun dalam wirausaha produk kuliner serta memiliki ketrampilan dasar dalam membuat kue sebelumnya. Tahap ke lima, pelaksanaan pelatihan.

\section{HASIL DAN KETERCAPAIAN}

\section{Identifikasi potensi perempuan Dusun Srumbung Gunung}

Hasil observasi dan wawancara lebih mendalam ditemukan ada enam orang ibu-ibu Dusun Srumbung Gunung yang sudah menyediakan menjadi rumahnya sebagai tempat penginapan yang disebut homestay menjadi target pelatihan. Mereka pada umumnya telah memiliki kemampuan dasar memasak masakan rumahan yang tradisional. Hasil evaluasi kegiatan peace camp yang dilaksanakan dengan total 30 peserta pada tanggal 29 30 Agustus 2020 di Balai Desa Poncoruso ditemukan bahwa ibu-ibu di Dusun Srumbung Gunung juga memiliki motivasi untuk memberdayakan dirinya sendiri. Ini ditunjukkan dari kesediaan para ibu-ibu untuk mempersiapkan dan menyediakan makanan kecil dan makan siang dalam acara tersebut. Namun, kesibukan para ibu mengurus anak-anak yang masih kecil dan ketrampilan memasak yang pas-pasan sehingga membuat mereka kurang percaya diri serta kurangnya atau bahkan tidak memiliki pengalaman berwirausaha. Oleh sebab itu, kegiatan pelatihan dan pendampingan terhadap ibu-ibu di Dusun Srumbung Gunung perlu untuk dilakukan. Ada dua jenis kegiatan yang dilakukan dalam rangka pemberdayaan perempuan, yaitu pelatihan pengelolaan homestay dan pelatihan inovasi kuliner.

\section{Pelatihan homestay dan pelayanan prima dengan konsep CHSE (Clean, Healthy, Safe and Environmentally Sustainable)}

Pelatihan homestay dengan konsep CHSE (Clean Healthy Safe and Environmentally Sustainable) pada tanggal 22 Agustus 2020. Homestay bukanlah rumah kosong yang disewakan, tetapi homestay didefinisikan sebagai usaha penyediaan akomodasi berupa rumah tinggal yang dihuni pemiliknya dan dimanfaatkan sebagian untuk disewakan (Permenparekraf, 2012). Secara umum, alat yang harus disiapkan homestay adalah kotak P3K dan tabung kebakaran. Kesiapan untuk menerapkan konsep CHSE juga perlu dilakukan. Peserta pelatihan ini ada enam orang ibu-ibu yang sudah memiliki komitmen untuk menjadikan rumahnya sebagai homestay. Suasana pelatihan homestay untuk sesi simulasi dapat dilihat pada Gambar 2.

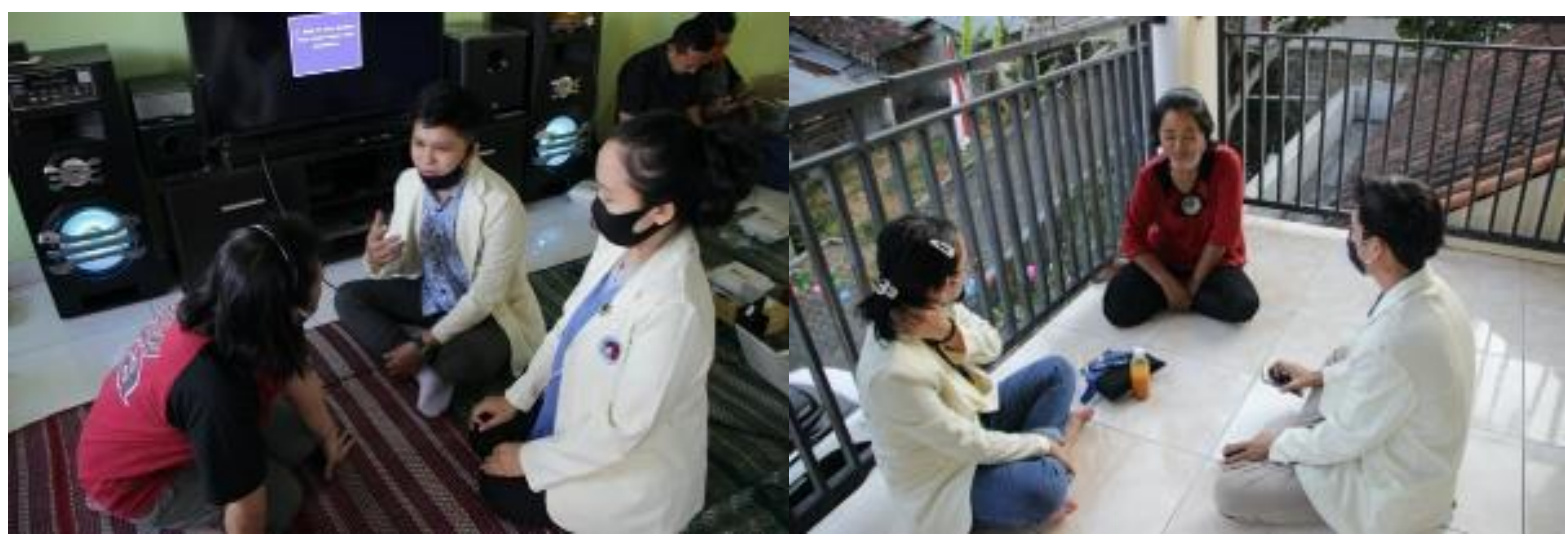

Gambar 2. Suasana Pelatihan Homestay- Sesi Simulasi

Pelatihan ini dibagi menjadi tiga sesi. Sesi pertama, tim pengabdian memperkenalkan konsep Sapta Pesona yang harus diusung dalam pengembangan homestay, yaitu meliputi keamanan, ketertiban, kebersihan, kesejukan, keindahan, keramahtamahan dan kenangan. Selain itu, disampaikan juga standar minimal untuk rumah yang layak digunakan sebagai homestay. Interaksi antara masyarakat lokal dan wisatawan menjadi daya tarik dan keunikan sendiri, di mana nilai-nilai tolerasi dan perdamaian dapat ditularkan kepada wisatawan yang menginap. Sesi kedua, peserta pelatihan belajar untuk melakukan $5 \mathrm{~S}$, yaitu senyum, salam, sapa, sopan dan santun dalam melayani tamu dengan lima standar elemen kualitas layanan. Lima elemen tersebut, meliputi 
elemen tangible (bukti fisik), empati, ketanggapan, keandalan dan jaminan. Sebagai penutup, sesi ketiga, yaitu sesi simulasi yang dilakukan antara para perempuan pemilik homestay dan mahasiswa sebagai wisatawan. Peserta pelatihan belajar untuk melakukan $5 \mathrm{~S}$ dalam melayani tamu dengan lima standar elemen kualitas layanan. Dari hasil simulasi, peserta pelatihan memiliki keramahtamahan dan kesabaran yang luar biasa. Mereka sangat antusias dan bersemangat. Selain harapan mendapatkan penghasilan, peserta pelatihan juga berharap dapat berkontribusi secara nyata program Desa Wisata Kreatif Perdamaian (DWKP).

\section{Pelatihan inovasi kuliner dan pemberian peralatan kuliner yang dibutuhkan}

Pelatihan inovasi kuliner dengan membuat bolen pisang dan tape dilakukan pada tanggal 19 September 2020. Pelatihan inovasi kuliner diikuti oleh 16 orang ilbu-ibu yang tergabung dalam Dawis 4 RT Dusun. Pofil peserta pelatihan inovasi kuliner ditunjukkan pada Gambar 3. Dari peserta yang mengikuti kegiatan inovasi kuliner, dua buruh pabrik kehilangan pekerjaan karena Pandemi Covid 19. Satu di antaranya tertarik untuk memulai usaha makanan kecil yang harapannya dapat menjadi makanan khas atau oleh-oleh khas dari Srumbung Gunung. Peserta ibu rumah tangga yang tidak memiliki pekerjaan, tertarik untuk melakukan usaha yang bisa dilakukan di rumah dikarenakan kesibukan mereka merawat anak yang masih kecil. Peserta UKM bakpao tertarik karena ingin melakukan diversifikasi produk sehingga dapat meningkatkan penghasilan dan berharap dapat memberikan pekerjaan kepada ibu-ibu lain di Dusun Srumbung Gunung.

Ada dua produk yang akan diajarkan cara pembuatannya oleh tim pengabdian kepada masyarakat dalam kegiatan ini, yaitu bolen pisang dan bolen tape. Penetapan kedua produk tersebut berdasarkan sembilan pertimbangan. Pertama, pisang adalah produk buah lokal yang banyak ditanam di Dusun Srumbung Gunung, tidak mengenal musim, murah dan mudah didapatkan. Kedua, tape terbuat dari singkong yang banyak ditanam di Dusun Srumbung Gunung dan mudah pembuatannya. Ketiga, bolen pisang dan tape adalah makan tradisional yang enak rasanya, banyak varian rasanya dan harga jualnya terbilang tinggi Keempat, resep bolen pisang dan tape, bahannya sangat sederhana dan mudah diperoleh bahkan di warung-warung terdekat

Kelima, alat yang digunakan untuk membuat sederhana. Pembuatan bolen pisang dan tape hanya memerlukan oven dan tidak memerlukan mixer. Keenam, tidak menggunakan obat-obatan dan pengawet, tetapi memerlukan teknik khusus. Ketujuh, pembuatan bolen membutuhkan waktu yang cukup lama dan harapannya adalah ibu-ibu dapat memproduksi dengan bekerja sama, sehingga kegiatan ini bisa mendukung organisasi pengelola pariwisata setempat. Kedelapan, penjualan bisa dilakukan melalui sistem PO (Purchasing Order) dan dapat dijual melalui pasar digital yang sudah dimiliki Dusun Srumbung Gunung, yaitu Pasar Dusun.

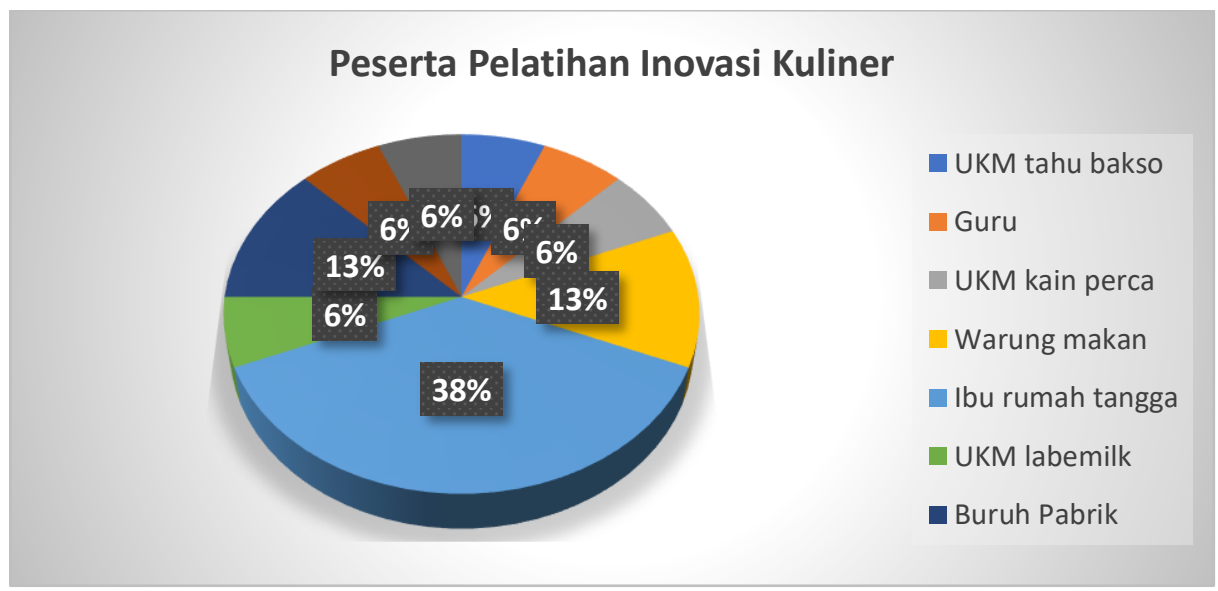

Gambar 3. Profil Peserta Pelatihan Inovasi Kuliner

Peserta pelatihan pada umumnya belum memiliki alat standar untuk pembuatan produk bolen pisang dan tape, yaitu oven. Pada kesempatan ini, tim pengabdian kepada masyarakat memberikan satu set oven dan alatalat yang diperlukan untuk membuat makanan atau jajanan yang diajarkan. Dalam sesi ini, peserta pelatihan melakukan praktek langsung dengan dipandu oleh instruktur dan resep yang telah diberikan dan mencicipi hasilnya. Dalam pelatihan ini diajarkan juga cara menghitung HPP (harga pokok produksi) dan menentukan margin keuntungan. Para ibu sangat antusias menunggu hasil. Proses mentoring dilakukan melalui whatsapp oleh tim pengabdian dan pembuatan video tutorial agar proses uji coba resep yang diberikan dapat berjalan dengan baik. Suasana pelatihan inovasi kuliner dan proses serah terima alat untuk membuat boleh pisang dan tapa ditunjukkan pada Gambar 4. 


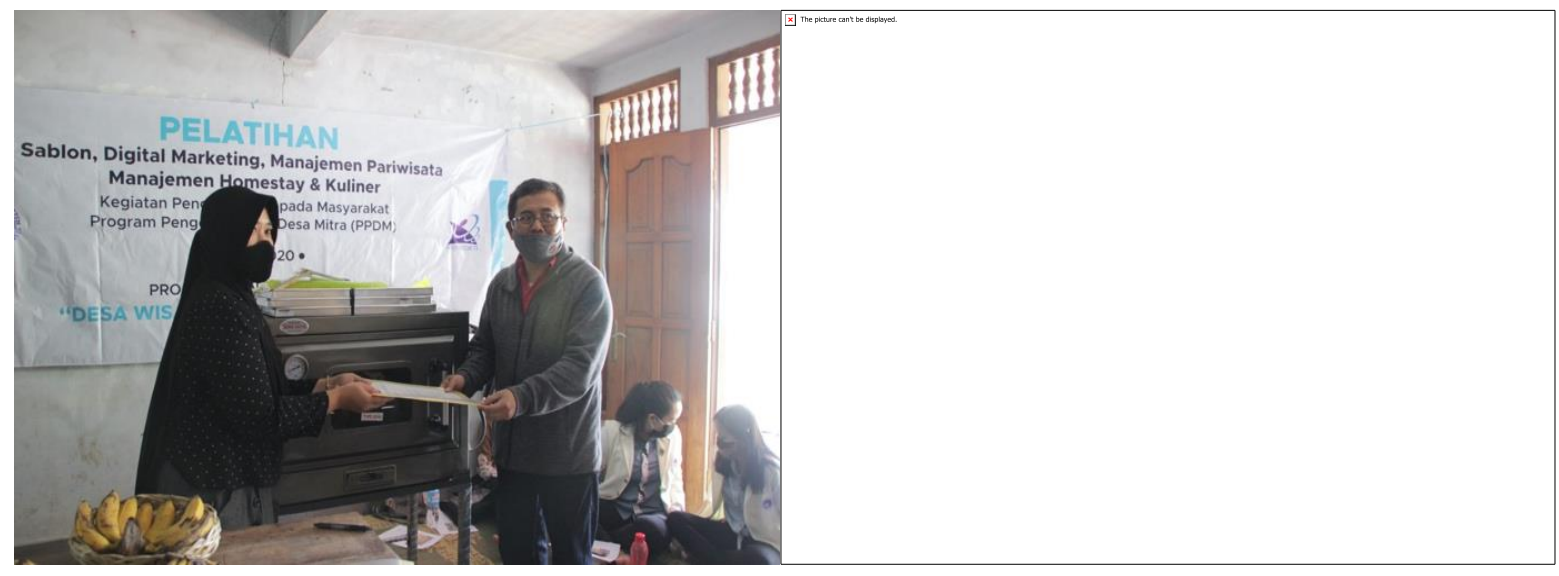

Gambar 4. Serah terima alat dan suasana saat pelatihan inovasi kuliner

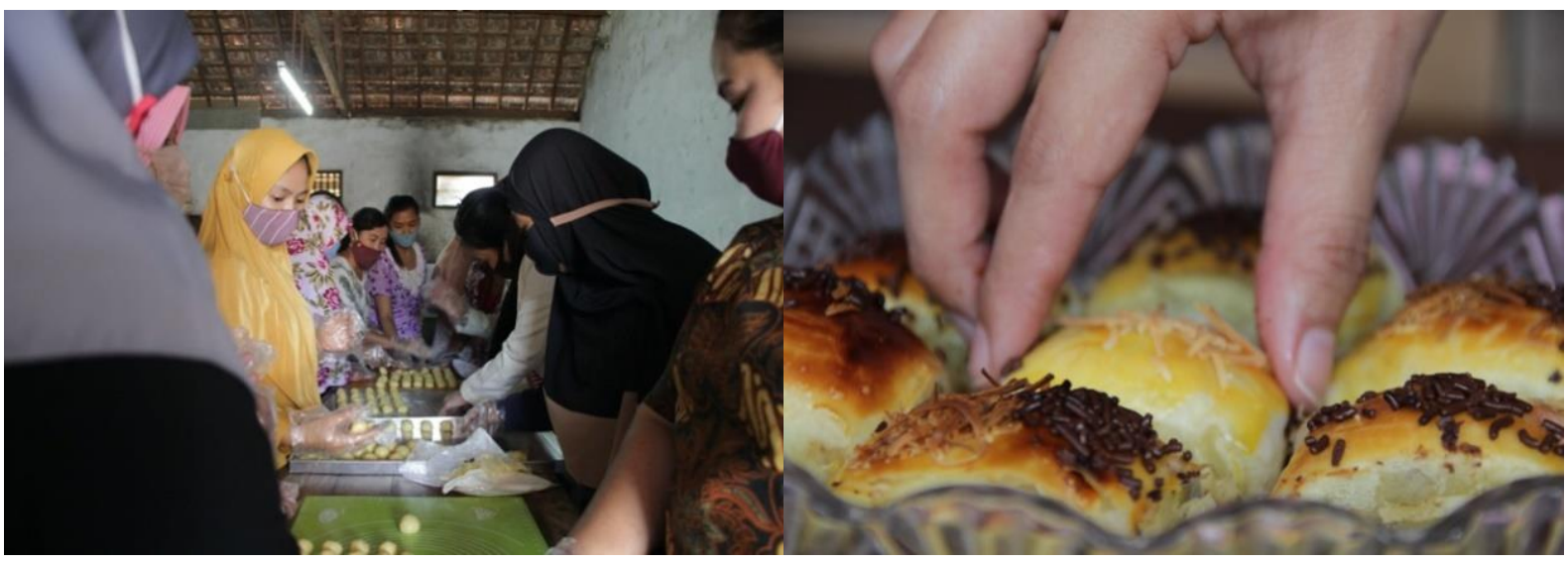

Gambar 5. Suasana praktik di sesi pelatihan inovasi kuliner dan produk hasil pelatihan

\section{Capaian kegiatan pengabdian kepada masyarakat}

Dengan adanya pandemi Covid 19, capaian kegiatan pemberdayaan perempuan dalam bidang pariwisata dari sisi ekonomi menjadi sulit untuk diukur. Pasalnya kegiatan homestay untuk menerima tamu/wisatawan belum dapat dilaksanakan di Dusun Srumbung Gunung. Namun, capaian kegiatan pengabdian kepada masyarakat untuk homestay dapat dilihat dari hasil pre-test dan post-test peserta pelatihan terkait kemampuan dan pemahaman homestay dan pengelolaannya. Hasil pre-test disajikan pada Gambar 6 dan 7. Hasil pre-test menunjukkan bahwa dari enam peserta pelatihan hanya dua orang (33 persen) yang mengetahui tentang usaha homestay, sisanya empat orang (67 persen) tidak mengetahui homestay dan cara pengelolaannya. Dari dua orang yang mengetahui tentang homestay, ditemukan satu orang tidak dapat menjelaskan dan satu orang sisanya tidak mampu menjelaskan dengan benar terkait homestay dan cara mengelolanya. Sedangkan hasil post-test yang dilakukan di akhir pelatihan menujukkan bahwa 83,33 persen peserta pelatihan sudah memahami dengan benar tentang homestay dan cara mengelola homestay yang berkualitas. 


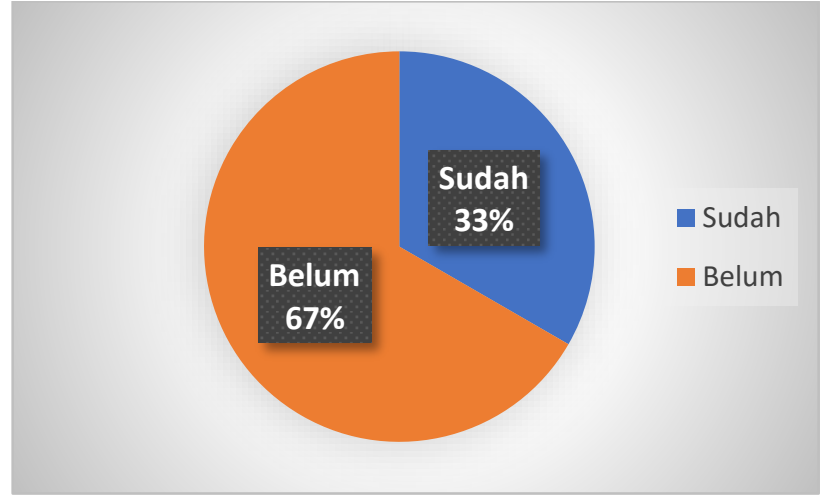

Gambar 6. Hasil Pre-test- peserta yang mengetahui homestay

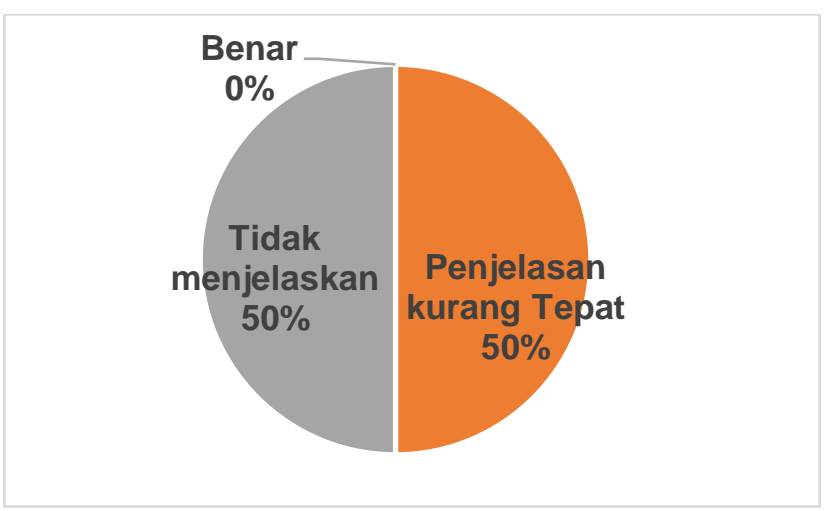

Gambar 7. Hasil Pre-test- peserta yang mampu menjelaskan pengelolaan homestay

Mentoring dan pendampingan terus dilakukan, khususnya kesiapan fasilitas standar dan konsep CHSE yang harus benar-benar diterapkan Selain keramatahamah dan nilai-nilai tolerasi serta perdamaian yang menjadi kekuatan, homestay di Dusun Srumbung Gunung harus menyiapkan diri untuk menjadi destinasi yang premium. Menurut UNWTO, 79 persen wisatawan mengubah rencana perjalanan dalam 6 bulan mendatang, 48 persen membatalkan perjalanan, 44 persen mengurangi perjalanan, 25 persen mengubah destinasi yang lebih mudah dijangkau dan 12 persen mengganti perjalanan internasional menjadi perjalanan domestik. Ditambah dengan hasil survei Travel Association, Covid 19 menjadi faktor utama dalam menentukan keputusan berwisata. Sebagai akibatnya, wisata lokal atau domestik diproyeksikan menjadi pilihan utama berwisata bagi wisatawan lokal saat dampak virus Covid 19 mulai mereda. Jika Dusun Srumbung Gunung bisa menangkap kesempatan ini dengan menyediakan homestay dengan suasana pedesaan maju yang sehat dan bersih, maka wisatawan lokal sekitar Ambarawa, Salatiga, Semarang dan kota-kota di Jawa Tengah akan menjadi wisatawan.

Tak berbeda jauh dengan kegiatan homestay, untuk kegiatan inovasi kuliner juga saat ini belum dapat diukur kesuksesannya dalam sisi ekonomi. Pemberdayaan adalah sebuah proses, termasuk inovasi kuliner. Pelatihan tidaklah cukup, tapi harus ada pendampingan, coaching dan mentoring dari praktek dan uji coba, desain kemasan dan presentasi produk, peralatan yang dipilih, bahan yang dipilih, penjualan produk dan yang paling sulit untuk dilakukan adalah kemampuan untuk berwirausaha. Dari model konseptual door, lock and key, kunci dari pemberdayaan itu adalah socio entrepreneurship. Diharapkan perempuan yang diberdayakan dapat memberdayakan perempuan yang lain. Dua orang ibu dari total 16 orang peserta akan didampingi sampai dapat menjual produk dan tidak hanya membawa dampak positif secara ekonomi, tapi juga dapat membangun kepercayaan diri para perempuan yang terlibat.

\section{KESIMPULAN}

Program pemberdayaan perempuan melalui pelatihan homestay dan inovasi kuliner adalah program yang tepat dilaksanakan, tetapi tetap memerlukan proses untuk melihat hasil. Perdebatan untuk melibatkan perempuan dalam pariwisata dengan segala keunikan dan karakteristik perempuan dapat terjawab dengan memberdayakan mereka dalam program homestay dan kuliner. Namun tetap diingat bahwa memberdayakan perempuan juga memiliki kendala, seperti kewajiban dan kesibukan di rumah, selain modal dan peralatan serta yang terpenting adalah keberanian untuk memulai usaha. Para Ibu yang belum pernah berwirausaha dan pekerjaan sebelumnya adalah buruh pabrik, juga memerlukan pendampingan yang lebih intens.

\section{UCAPAN TERIMA KASIH}

Penulis mengucapkan terima kasih kepada RISTEK DIKTI untuk dana yang diberikan sehingga kami dapat menjalankan program kegiatan Pengabdian kepada Masyarakat dalam Program Pengembangan Desa Mitra pada tahun 2020 di Dusun Srumbung Gunung, Desa Poncoruso, Kecamatan Bawen, Kabupaten Semarang. 


\section{DAFTAR PUSTAKA}

Beeton, S. 2019. Community Development through Tourism. Community Development through Tourism, January. https://doi.org/10.1071/9780643093881

Fowler, A. 2000. NGDOs as a moment in history: Beyond aid to social entrepreneurship or civic innovation? Third World Quarterly, 21(4), 637-654. https://doi.org/10.1080/713701063

Irena, A. 2009. Women empowerment through tourism - From social entrepreneurship perspective. Ong Siaw Thien, 56.

Oxaal, Z., \& Baden, S. 1997. Gender and empowerment: definitions, approaches and implications for policy. 44(40), 38. http://www.bridge.ids.ac.uk/sites/bridge.ids.ac.uk/files/reports/re40c.pdf

Sen, P. 2007. Ashoka's big idea: Transforming the world through social entrepreneurship. Futures, 39(5), 534-553. https://doi.org/10.1016/j.futures.2006.10.013

Studi, P., Kajian, M., \& Udayana, U. (n.d.). Empat srikandi kuliner bali: peran perempuan dalam pembangunan pariwisata berkelanjutan 1.01, 65-94.

Van der Cammen, S. 1997. Involving Maasai women. In L. France (Ed.), The earthscan reader in sustainable tourism (pp. 162-163). London: Earthscan.

Wiser Earth. 2005. Women's Empowerment. Retrieved 15 April 2009, from http://www.wiserearth.org/aof/346 